Research Article

\title{
Communication Skills for Interns: Evolution and Assessment of a Training Workshop in a Medical College of New Delhi
}

\author{
Surabhi Sethi', Geeta Pardeshi', Jugal Kishore ${ }^{3}$
}

${ }^{1}$ Assistant Professor, Dept. of Community Medicine, North DMC Medical College and Hindu Rao Hospital, Delhi, India.

${ }^{2}$ Professor, ${ }^{3}$ Director-Professor and Head, Dept. of Community Medicine, VMMC and Safdarjung Hospital, New Delhi, India. DOI: https://doi.org/10.24321/2455.9199.201908

\section{I $\quad \mathbf{N} \quad \mathbf{F} \quad \mathbf{O}$}

\author{
Corresponding Author: \\ Surabhi Sethi, Dept. of Community Medicine, \\ North DMC Medical College and Hindu Rao \\ Hospital, Delhi, India. \\ E-mail Id: \\ drsurabhisethi@gmail.com \\ Orcid Id: \\ https://orcid.org/0000-0001-8415-1065 \\ How to cite this article: \\ Sethi S, Pardeshi G, Kishore J. Communication \\ Skills for Interns: Evolution and Assessment of \\ a Training Workshop in a Medical College of \\ New Delhi. Int J HealthCare Edu \& Med Inform \\ 2019; 6(2): 17-22.
}

Date of Submission: 2019-05-15

Date of Acceptance: 2019-06-01

\section{$\begin{array}{llllllllllllll}\mathbf{A} & \mathbf{B} & \mathbf{S} & \mathbf{T} & \mathbf{R} & \mathbf{A} & \mathbf{C} & \mathbf{T}\end{array}$}

Considering the incidents of violence in health care setups reported from all over the country, we developed a one-day workshop to orient interns towards communication, conflict management, stress management and prescription writing skills. The objective was to impart training on effective communication and conflict management skills which are crucial to reduce the incidence of workplace violence, and improve the quality of services provided in our hospital. We describe the evolution of content and assessment of the workshops conducted for interns posted in the Department of Community Medicine during a period of one year since 01.01.2018.

After extensive review of literature, we prepared interactive presentations, developed games, innovative activities and role plays in context of the doctor-patient relationship. We modified the teaching learning methods to increase participant involvement, and added the use of video clips and flip-charts. Assessment of take home messages was done using an anonymous open-ended questionnaire $(n=86)$. Codes were identified for the responses under three domains i.e. communication skills, conflict management and prescription writing. Likert scale was used to rate statements concerning the overall feedback for the workshop in a subset of interns $(n=54)$.

The most frequently reported take-home messages were on improving listening skills $(41,48 \%)$, learning the various conflict management techniques $(61,71 \%)$ and writing generic names and correct dosages $(54,63 \%)$, in each of the three sessions held on effective communication, conflict management and prescription writing, respectively. Majority of the interns strongly agreed that the workshop was needed (31,57\%), increased their knowledge $(28,52 \%)$, the small group exercises were beneficial $(36,67 \%)$ and that they would implement the skills they learnt (34,64\%). In conclusion, interactive, small group workshops on communication skills and conflict management for interns are a felt need, and have motivated them to implement various soft skills in their place of work.

Keywords: Communication Skills, Conflict Management, Workshop, Assessment, Interns 


\section{Introduction}

A hospital - where patients fight for their life, and where doctors fight alongside to save them- in all its essence-is a battleground. Over the years, however, the sanctity of this battleground has deteriorated to one where doctors and patients, more often than desired, end up fighting, quite literally, against each other. The rising incidents of violence in hospitals all over the country, are testimony to this statement. ${ }^{1-6}$

The medical profession is one of the most stressful professions in the world, where overburdened and underpaid doctors work long hours amidst a competitive, resource-scarce environment, keeping their personal wellbeing at bay. Patients and their attendants are not only battling their own illness, illiteracy and ignorance, but also the financial hardships of the common man. Violence in the healthcare setting stems from these stressors, with miscommunication often being the precipitating factor. ${ }^{1,3,4,6}$

With training and practice, effective communications skills can be honed. In addition to better outcomes, they not only help build rapport and trust, increase patient and professional satisfaction, but also decrease the probability of conflicts and violence by easing tensions. ${ }^{7}$ Medical interns are among the newest and most inexperienced group of medical professionals, prone to conflicts. ${ }^{5}$ At the same time, it is plausible that they are the youngest, most enthusiastic and mouldable learners, in whom soft skills can be inculcated from the very beginning of their medical practice.

With the goal of enhancing the quality of health services provided in our hospital, a one-day workshop was developed to orient interns towards communication, conflict management, stress management and prescription writing skills. In this paper, we describe the evolution of content, and assessment of theworkshop conducted for interns posted in the Department of Community Medicine, over a period of one year.

\section{Methodology}

Every two months, the Department of Community Medicine in Vardhman Mahavir Medical College and Safdarjung Hospital, New Delhi receives a fresh batch of 30-40 interns, who are subsequently posted by rotation to the rural and urban health centres, as well as the Integrated Counselling and Testing Centres (ICTC) and Directly Observed Treatment Short-course (DOTS) centres.

We conducted the workshop for the interns on the first day of their posting in the department, with the view that they get the opportunity to implement the skills they learn, over the remainder of their posting. Hence in 2018, we conducted 6 such workshops, beginning with the first batch on the $1^{\text {st }}$ of January, 2018.

Over the course of the year, the first three workshops were used to refine the content of the sessions.We diligently documented the process of the development of contents of the workshop and report the evolution process.

The content of the workshop was standardized during this period and used in the next three workshops. We sought the feedback from the subsequent three batches using a feedback format which was developed as an anonymous, structured, open-ended questionnaire to assess the take home messages and learning from each session. The interns were also asked which skills they would like to implement in the clinical setting. Responses to open ended questions enquiring key take-home messages were independently coded and analysed. A Likert scale was also used to rate statements concerning the overall feedback for the workshop among last two batches of interns attending the workshop. Results are expressed as frequencies and proportions.

\section{Result}

\section{Evolution of the Training Program}

At the outset, faculty and senior residents of the department were allotted the topics of communication skills, the right attitude for doctors, prescription writing, stress management and conflict management. After extensive reading and review of literature, interactive presentations were prepared and group activities like role plays were planned. Informal feedback from some of the 115 interns who attended these workshops was motivating, however interns felt the need for more practical involvement and less theoretical components. The content of the workshop, and duration of the sessions were slightly modified over the subsequent two batches, however the feedback from interns remained similar. It was also observed that facets of the doctor-patient relationship remained untouched.

To expand the scope of the workshop to include first year postgraduate students, we invited professionals and communication experts to conduct the sessions. The response was however not well appreciated, as the content was not customized to the needs of the young doctors. Realizing the need for combining the best of both the worlds, in-house efforts were made to redesign the sessions and customize it to the needs of our hospital.

We restructured and developed games, innovative activities and role plays in context of the doctor-patient relationship, and common scenarios faced in every ward. We held discussions with officials of the institute's Grievance Redressal Cell to develop examples of real life scenarios regarding miscommunications and conflicts. We also modified the teaching learning methods to increase participant involvement, and added the use of video clips 
and flip-charts along with projecting the presentation. We conducted the sessions for the faculty and residents of our department to give us candid feedback, and refined the content to incorporate their suggestions as well.
This process took six months, and the revised content was ready for implementation in July 2018. The process of development of the revised content of the workshop is elaborated in Figure 1.

Felt need of the workshop, and preliminary discussion on potential topics for inclusion done.

\section{Extensive literature review undertaken. Online training courses completed. Professional and expert opinions invited.}

Presentation made in the department, inputs from all faculty and residents received.

Discussion with Grievance Redressal Cell to develop group activities and games based on real events.

Feedback from every step incorporated, leading to development of final content of the workshop.

Figure I.Process describing the evolution of the content of the workshop

Table I.Comparison of the original and the modified versions of the topics and methods of the workshop

\begin{tabular}{|c|c|c|c|}
\hline \multicolumn{2}{|c|}{ Original version } & \multicolumn{2}{|r|}{ Modified Version } \\
\hline Topics & Methods & Topics & Methods \\
\hline $\begin{array}{l}\text { Communication skills } \\
\text { for interns: The need } \\
\text { of the hour }\end{array}$ & $\begin{array}{l}\text { Informal welcome } \\
\text { address }\end{array}$ & $\begin{array}{l}\text { Communication skills } \\
\text { for interns: The need } \\
\text { of the hour }\end{array}$ & $\begin{array}{l}\text { Lecture with Powerpoint presentation } \\
\text { displaying newspaper articles of rising } \\
\text { incidents of violence in the country. }\end{array}$ \\
\hline $\begin{array}{l}\text { The right attitude for } \\
\text { doctors }\end{array}$ & Lecture & $\begin{array}{l}\text { Doctor-patient } \\
\text { relationship }\end{array}$ & $\begin{array}{l}\text { Interactive Lecture with powerpoint, } \\
\text { Discussion, Video }\end{array}$ \\
\hline $\begin{array}{c}\text { Effective } \\
\text { communication }\end{array}$ & $\begin{array}{l}\text { - Lecture on } \\
\text { importance of } \\
\text { communication, } \\
\text { its model and } \\
\text { barriers. } \\
\text { Lecture with } \\
\text { activity on tips } \\
\text { for effective } \\
\text { communication } \\
\text { Role play } \\
\text { demonstrating } \\
\text { good } \\
\text { communication } \\
\text { with patients. }\end{array}$ & $\begin{array}{c}\text { Effective } \\
\text { Communication }\end{array}$ & $\begin{array}{l}\text { - } \quad \text { Lecture with powerpoint presentation } \\
\text { on model of communication } \\
\text { - } \quad \text { Lecture and activity on identifying } \\
\text { barriers of communication. } \\
\text { - } \quad \text { Activity for non-verbal communication } \\
\text { and demonstration of facial } \\
\text { expressions. } \\
\text { - Self-assessment of listening skills by } \\
\text { - scoring. } \\
\text { Lecture on improving listening and } \\
\text { remembering } \\
\text { Role play demonstrating both poor } \\
\text { and good communication with } \\
\text { patients. }\end{array}$ \\
\hline
\end{tabular}




\begin{tabular}{|c|c|c|c|}
\hline Conflict management & Lecture & Conflict management & $\begin{array}{l}\text { - } \quad \text { Lecture with PPT presentation on } \\
\text { causes on conflicts. } \\
\text { Elaboration of conflict resolution } \\
\text { techniques with examples and } \\
\text { discussion on real situations } \\
\text { - } \text { Activity to understand difference in } \\
\text { social worlds of doctor and patient. } \\
\text { Participant Activity to demonstrate } \\
\text { difference between debate and } \\
\text { discussion. }\end{array}$ \\
\hline $\begin{array}{c}\text { Communication with } \\
\text { colleagues/ critical } \\
\text { information/ taking } \\
\text { consent }\end{array}$ & Group activities & $\begin{array}{l}\text { Communication with } \\
\text { colleagues/ critical } \\
\text { information/ taking } \\
\text { consent }\end{array}$ & Group activities with modified scenarios. \\
\hline Prescription Writing & Lecture & Prescription Writing & $\begin{array}{l}\text { Lecture with PPT showing real prescription } \\
\text { errors.Demonstration of sample } \\
\text { prescription before and after lecture. }\end{array}$ \\
\hline Stress management & Lecture & Stress management & $\begin{array}{l}\text { Lecture with demonstration and } \\
\text { activity of breathing techniques, video } \\
\text { demonstrations of tips. }\end{array}$ \\
\hline
\end{tabular}

A comparison of the original and the final, modified schedule is described in Table 1. While the original workshop involved mainly lectures with PowerPoint presentations and a few activities for the participants; in the modified version, a more interactive, activity-based approach was used; more audio-visual aids and group activities were incorporated.

Table 2.Key take-home messages reported by workshop participants

(Multiple Responses Present)

\begin{tabular}{|c|c|c|c|}
\hline Session & Responses $(\mathrm{N}=86)$ & $\mathbf{n}$ & $\%$ \\
\hline \multirow{9}{*}{$\begin{array}{l}\text { Effective } \\
\text { Communication }\end{array}$} & Tips for improvement of their Listening skills & 41 & 47.7 \\
\hline & Communication Model : Importance of feedback & 34 & 39.5 \\
\hline & Correct Attitude and empathy towards patients & 33 & 38.4 \\
\hline & Nonverbal communication : Interpreting and use & 16 & 18.6 \\
\hline & Communication Barriers : What they are & 11 & 12.8 \\
\hline & Importance of Communication in the medical profession & 8 & 9.3 \\
\hline & Language : Using simple, understandable words & 7 & 8.1 \\
\hline & Doctor patient relationship & 6 & 7.0 \\
\hline & Remembering : How to make the patient remember messages & 2 & 2.3 \\
\hline \multirow{5}{*}{$\begin{array}{c}\text { Conflict } \\
\text { Management }\end{array}$} & $\begin{array}{l}\text { Techniques of Conflict Management : Collaboration, compromise, } \\
\qquad \text { accommodation, etc. }\end{array}$ & 61 & 70.9 \\
\hline & Importance of Communication skills in managing conflicts. & 26 & 30.2 \\
\hline & Apologizing, and owning one's mistakes & 25 & 29.1 \\
\hline & Remaining Calm/ Composed & 8 & 9.3 \\
\hline & Use of Teamwork to resolve conflicts & 7 & 8.1 \\
\hline \multirow{4}{*}{$\begin{array}{l}\text { Prescription } \\
\text { Writing }\end{array}$} & Will be careful in writing generic names and correct dosages. & 54 & 62.8 \\
\hline & Handwriting: will write legibly and in capital letters & 47 & 54.7 \\
\hline & Super/ subscript : Signing and writing the doctor's details & 11 & 12.8 \\
\hline & Will write provisional diagnosis and history. & 8 & 9.3 \\
\hline
\end{tabular}




\section{Assessment of the Workshop}

Of the 89 interns that comprised the last three batches from July to December, and were administered the questionnaire on key take home messages, 86 (97\%) gave their responses (Table 2). The most frequently reported take-home messages were on improving listening skills (47.6\%), learning the various conflict management techniques (70.9\%) and writing generic names and correct dosages (62.8\%), in each of the three sessions held on effective communication, conflict management and prescription writing, respectively.

Constructive feedback was received that helped us modify the logistics of the workshop as well. Some comments from the participants are described verbatim. As the workshop extended from 9 am to $4 \mathrm{pm}$, some interns felt that the duration was too long, and too much content was shared in that time.

"The workshop was good, but the time period for the workshop can be reduced a little."

To provide a quick, working lunch that appeals to the young interns, we would provide personal pizzas. However few interns were unhappy and wrote about providing nutritious food for lunch. Their feedback was incorporated and the subsequent batches were provided with thalis (a balanced north Indian meal).

"Encouraging balanced diet, should not provide pizza in break, a thali would be better"

The interns also felt the need to expand the scope of the workshop, and requested that this workshop be conducted for seniors, residents and the patients as well.

"Educate the patients and seniors also about all this (communication skills \& conflict management)"

Those interns who were posted in the Community Medicine department in the latter half of the year, expressed their desire of having attended the workshop in the beginning of the year itself.

"Maybe this (workshop) can be done at the start of the internship"

Overall feedback for the workshop was sought from last two batches of interns $(n=54)$. The interns provided us with encouraging responses for the final, modified version of the workshop. (Table 3) They all agreed/ strongly agreed that the workshop met its objectives, the small group exercises were beneficial, and that the workshop was needed in their profession. Majority of them also strongly agreed that the workshop increased their knowledge, and that they would implement the skills they learnt from the workshop at their workplace.
Table 3.Overall feedback for the workshop

\begin{tabular}{|c|c|c|c|}
\hline Feedback statements & $\begin{array}{c}\text { Strongly } \\
\text { Agree }\end{array}$ & Agree & $\begin{array}{c}\text { Neither } \\
\text { agree nor } \\
\text { disagree }\end{array}$ \\
\hline $\begin{array}{c}\text { The Workshop met its } \\
\text { objectives(n=53) }\end{array}$ & $\begin{array}{c}25 \\
(47 \%)\end{array}$ & $\begin{array}{c}28 \\
(53 \%)\end{array}$ & 0 \\
\hline $\begin{array}{c}\text { The small group } \\
\text { exercises were } \\
\text { beneficial (n=54) }\end{array}$ & $\begin{array}{c}36 \\
(67 \%)\end{array}$ & $\begin{array}{c}18 \\
(33 \%)\end{array}$ & 0 \\
\hline $\begin{array}{c}\text { This Workshop } \\
\text { is needed in my } \\
\text { profession ( } n=54)\end{array}$ & $\begin{array}{c}31 \\
(57 \%)\end{array}$ & $\begin{array}{c}23 \\
(42 \%)\end{array}$ & 0 \\
\hline $\begin{array}{c}\text { The workshop } \\
\text { increased my } \\
\text { knowledge (n=54) }\end{array}$ & $\begin{array}{c}28 \\
(52 \%)\end{array}$ & $\begin{array}{c}22 \\
(41 \%)\end{array}$ & $4(7 \%)$ \\
\hline $\begin{array}{c}\text { I Will implement the } \\
\text { skills I learnt today at } \\
\text { my workplace (n=53) }\end{array}$ & $\begin{array}{c}34 \\
(64 \%)\end{array}$ & $\begin{array}{c}18 \\
(33 \%)\end{array}$ & $1(3 \%)$ \\
\hline
\end{tabular}

\section{Discussion}

A study conducted at our institute in 2016 reported that almost half of the doctors ( $47 \%$ ) had experienced violence during work hours in past 12 months, where patients or their relatives were perpetrators in most of the cases. Majority $(87.3 \%)$ of the reported cases were of verbal violence while $8.6 \%$ of the cases were of physical violence, with younger doctors being more prone to facing physical violence. ${ }^{5}$ Our interns had a similar attitude compared to medical and allied health care professionals around the world regarding the importance of good communication skills, and the role of communication skills in resolution of conflicts. ${ }^{8-10}$

The incorporation of multiple group activities, using examples of real scenarios and role plays may have had a major contribution in the success of the workshop, by keeping the students engaged and facilitating experiential learning. Other authors have also described the effectiveness of using role plays to teach communication skills to undergraduate students in different departments. ${ }^{11,12}$

The many years of professional medical education may not be sufficient for the development of good communications skills, as the current curriculum lacks standardized training on soft skills. Recognizing this deficit, and to ensure that the country is producing doctors who are competent communicators, the Medical Council of India has proposed a new structured longitudinal programme on attitude, communication and ethics: AETCOM module. ${ }^{13}$ Many of 
the topics and methods covered in our workshop can be incorporated while conducting AETCOM sessions.

The interns' comments and ratings of the overall workshop motivated us to continue and upscale the activity to reach out to other doctors and different cadres of health workers. Until a critical number of trained workers is achieved, it would be difficult to expect concrete changes in the overall work environment with respect to increase in patient satisfaction and decrease in incidence of conflicts.

The workshop had its limitations of time constraints, as a lot of knowledge and skills needed to be shared, in one day. The workshop could only sensitize interns and increase the knowledge regarding the importance of these soft skills, and tips for improving them. As the long term impact of the workshop could not be assessed, it is difficult to predict whether the knowledge gained was translated to action on their behalf. This limitation has also been reported by other authors that have conducted one day training courses, followed by immediate assessment. ${ }^{14}$ Without repeated training and a conducive working environment, behaviour change may be difficult to sustain.

\section{Conclusion}

The workshop evolved from a lecture based format to an interactive, activity based structure with inputs from domain experts, participants, and literature review. The study identified important take-home messages for interns in terms of improving the listening skills, imbibing conflict management techniques and writing generic drug names in prescriptions.

In conclusion, the overall feedback was positive, and workshops on communication skills and conflict management for young medical professionals are a felt need and have motivated them to implement various soft skills in their place of work.

\section{Acknowledgements}

The authors acknowledge the contributions of Dr. Timiresh Das, Dr. Sneha Kumari, Dr. Rupsa Bannerjee and Ms. Alka Mishra for co-developing the content of the workshop and conducting the sessions.

\section{Conflict of Interest: None}

\section{References}

1. Nagpal N. Incidents of violence against doctors in India: Can these be prevented? NatI Med J India 2017; 30(2): 97-100.

2. Ambesh P. Violence against doctors in the Indian subcontinent: A rising bane. Indian Heart J 2016; 68: 749-750.

3. Reddy IR, Ukrani J, Indla V, Ukrani V. Violence against doctors: A viral epidemic? Indian J Psychiatry 2019;

\section{1: S782-5.}

4. Ghosh K. Violence against doctors: A wake-up call. Indian J Med Res 2018; 148: 130-133. DOI: 10.4103/ ijmr.IJMR_1299_17.

5. Kumar M, Verma M, Das T, Pardeshi G, Kishore J, Padmanandan A. A Study of Workplace Violence Experienced by Doctors and Associated Risk Factors in a Tertiary Care Hospital of South Delhi, India. J Clin Diagn Res 2016; 10(11): LC06-LC10.

6. Anand T, Grover S, Kumar R, Kumar M, Ingle GK. Workplace violence against resident doctors in a tertiary care hospital in Delhi. Natl Med J India 2016; 29: 344-348.

7. Wolfe AD, Hoang KB, Denniston SF. Teaching conflict resolution in medicine: lessons from business, diplomacy, and theatre. MedEdPORTAL 2018; 14: 10672. https://doi.org/10.15766/mep_2374-8265.10672.

8. Zalihic A, Obrdalj EC. "Fundamental communication skills in medical practice" as minor elective subject. Acta Medica Academica 2014; 43(1): 87-91.

9. Tavakol M, Murphy R, Torabi S. A needs assessment for a communication skills curriculum in Iran. Teach Learn Med 2005; 17(1): 36-41.

10. Brock D, Abu-Rish E, Chiu CR, Hammer D, Wilson S, Vorvick $L$ et al. Interprofessional education in team communication: working together to improve patient safety. BMJ Qual Saf 2013; 22(5): 414-423.

11. Nair BT. Role play - An effective tool to teach communication skills in pediatrics to medical undergraduates. J Educ Health Promot 2019; 8: 18.

12. Lavanya SH, Kalpana L, Veena RM, Bharath Kumar VD. Role-play as an educational tool in medication communication skills: Students' perspectives. Indian J Pharmacol 2016; 48: S33-6.

13. Medical Council of India. Attitude, Ethics and Communication (AETCOM) Competencies for the Indian Medical Graduate,2018. Available from: https:// www.mciindia.org/CMS/wp-content/uploads/2019/01/ AETCOM_book.pdf [Last accessed on 2019 Dec 25].

14. Leaming-Van Zandt KJ, Zhu H, Banuelos RC, Lopez MA, Hsu DC. Impact of a Pediatric-Focused Communication Course on Patient/Caregiver-Perceived Physician Communication Skills in a Pediatric Emergency Department. Pediatr Emerg Care. 2019 Dec 16. doi: 10.1097/PEC.0000000000001950. [Epub ahead of print]. 